\title{
Towards Measurable and Auditable Efficiency Gains in the Flemish Public Sector
}

\author{
Jesse Stroobants • Geert Bouckaert
}

Published online: 16 October 2012

(C) Springer Science+Business Media, LLC 2012

\begin{abstract}
This article supports the Flemish Government's efforts to improve the efficiency in the public sector, but points out that efficiency has to be considered in the broader context of a well-performing and well-functioning public sector. After describing the main motives for efficiency improvement, the article provides some insights into the concept of public sector efficiency gains. Within the discussion of their required characteristics, we focus mainly on the measurability and auditability conditions. We employ a phased approach for the measurement process of efficiency gains, going from the identification of potential savings to the reporting of the actual achieved results.
\end{abstract}

Keywords Public sector $\cdot$ Efficiency $\cdot$ Efficiency gains $\cdot$ Measurement $\cdot$ Flanders

\section{Introduction}

The Flemish Government statement 2009-2014 and the 'Flanders in Action (ViA) Pact $2020^{\prime}$ objectives to get Flanders ${ }^{1}$ in the top five of European regions, devote central attention to a more efficient and effective government (Vlaamse Regering 2009; ViA Pact 2020 2009). Moreover, the Flemish government strives for a better, more responsive and more client-oriented public sector. In the trajectory toward reaching the ViA-goals, all levels of government in Flanders, both central and local, have to realize substantial efficiency gains by 2020, to catch up with comparable top European regions, and to improve the quality of public services for people and

\footnotetext{
${ }^{1}$ Flanders is the Dutch-speaking, northern part of the Belgian federal state. The Flemish community (just like the French- and German-speaking communities) has legal responsibilities within thirteen policy areas including economy, welfare, education, culture, sports, transport, environment and public health. These domains are no longer national policy areas and thus come within the purview of the Flemish Government.

This article is based on research conducted within the frame of the Policy Research Centre on Governmental Organization in Flanders (SBOV II - 2007-2011), funded by the Flemish government. The views expressed herein are those of the authors and not those of the Flemish government.
}

J. Stroobants $(\bowtie) \cdot$ G. Bouckaert

Public Management Institute, University of Leuven, Parkstraat 45 3609, 3000 Leuven, Belgium

e-mail: jesse.stroobants@soc.kuleuven.be 
businesses (ViA Pact 2020 2009). Furthermore, the current economic and financial context, together with long-term social, demographic and environmental issues, requires governments to improve their own performance and to provide more and better services with fewer resources (Peters et al. 2011; Boyle and MacCarthaigh 2011; Leslie and Canwell 2010; Vertinsky 2009). In short, public sector efficiency is high on the political and administrative agenda today, both in Flanders and abroad.

In its striving for a more efficient public sector, the Flemish Government does not stand alone. In 2010, it has ordered the Council of Administrators-General ${ }^{2}$ (the board of the highest senior civil servants) to establish a multi-annual program that should lead to permanent and substantial efficiency gains in the Flemish public sector. The final text of this program, titled 'Decisive Governance' (Slagkrachtige Overheid), was approved by the Flemish Government in May 2011 (Vlaamse Regering \& College van Ambtenaren-Generaal 2011).

Such government-wide programs for realizing efficiency gains in the public sector are not restricted to Flanders. In the recent past, similar efficiency initiatives are also undertaken in neighboring countries. In the UK, for example, there was the Gershon Efficiency Programme that was implemented between 2004 and 2008 (Gershon 2004). And since 2007, the Central Government Renewal Program is running in the Netherlands (Ministerie van Binnenlandse Zaken 2007). These initiatives include guidelines and best practices that can be useful for Flanders and that can support the Flemish government in the design and the implementation of its own public sector efficiency program.

This article is written to fulfill a supporting and complementary role to the existing efficiency initiatives within the Flemish administration. This means, for example, that relevant literature and concrete experiences of other countries (such as the above mentioned programs) were studied to see what could be learnt from them. We agree that there is already a lot said about improving governmental efficiency. However, this article aims to bring together this diverse body of knowledge about efficiency gains into a coherent whole, and seeks to reach consensus about what can be understood under the concept of efficiency gains. In the first section, we consider efficiency within the broader context of public sector performance. After identifying the main incentives for improving governmental efficiency, we describe different ways and types of achieving efficiency gains, and we discuss their required characteristics. A substantial part of this article is devoted to the measurability and auditability conditions of efficiency gains. Hereby, we develop a phased approach for the measurement process of efficiency gains, starting with identifying potential savings and moving to the reporting of the final results. Finally, the article stresses the importance of audit as a supporting element of the measurement and reporting process, and as an instrument for the validation and control of the reported efficiencies.

\section{Public sector efficiency in the broader context of performance}

In order to assess the performance of the public sector, not only (quantitative and qualitative) information about the different elements of the public sector production process is needed, namely the resources used (inputs), the activities carried out

\footnotetext{
${ }^{2}$ The Council of Administrators-General is a permanent administrative body, established to enforce the political-administrative dialogue and to harmonize government-wide governance issues.
} 
(throughput), the goods/services produced (outputs) and the effects achieved (outcomes). Also of major importance are the relationships between the different elements of the public sector transformation process, being respectively economy, efficiency, effectiveness and cost-effectiveness. Figure 1 illustrates and defines these four ratio indicators (Bouckaert and Auwers 1998).

It is important to emphasize that these ratios of economy, efficiency and effectiveness should not be considered independently from each other. The discussion about a well-functioning public sector must be held within the wider performance context, and cannot be confined to a single story of an efficient or an effective public service (SERV 2009). Combining efficiency ('doing things right') with effectiveness ('doing the right things') is a duty for every government. In the current climate, this debate takes on new significance. As Bartlett (2009) states, for the next decade the most urgent public policy question will be: how can public services achieve more for less — providing services that meet people's needs (i.e. effectiveness), while costing less (i.e. economy and efficiency)?

We recognize that cutting public spending is indispensable in the present financial and economic situation. To balance Flanders' budget (as premised by the Flemish Government), savings of 376,6 million Euros had to be obtained in 2011 (Vlaamse Regering 2010), and in 2012, due to lower growth expectations, even 560,8 million Euros has to be saved (Muyters 2012). Hence, the real question is: where and how will public spending be cut, and on what basis will these decisions be made? The natural tendency for the government will be to continue what it is doing, only more cheaply: by reducing unit costs in procurement, by cutting up-front investment for long-term change, by reducing the number of civil servants in a blunt way, or - even worse - by 'salami slicing' which means making across-the-board percentage cuts in departmental budgets (Bartlett 2009). These strategies might secure initial savings, and might be useful in the short term in the current financial context, but can make things more expensive in the longer run. To illustrate this, we can refer to a situation in which the number of departmental FTEs is being reduced due to budgetary reasons, but then afterwards activities have to be outsourced externally to highlypaid consultants.

Besides direct cost-saving actions, also initiatives towards achieving efficiency gains are high on the political agenda today, both in Flanders and in neighboring countries (Mandl et al. 2008). However, as mentioned above, this attention for

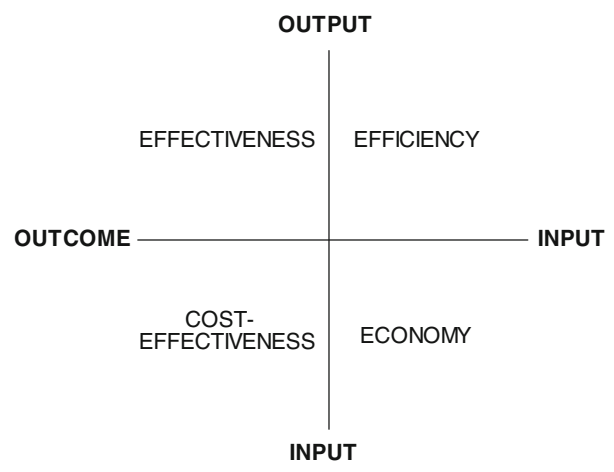

Fig. 1 Relations between input, output and outcome 
realizing efficiency savings has to be viewed within a broader performance framework, in which also the aspects of quality and effectiveness are taken into account. No matter how efficient a public service is made in monetary terms, if it does not solve the problem it is intended to solve, or does not achieve the desired outcomes, it is a poor use of public money. More importantly, it will also end up costing more, because either unhappy citizens who are not getting what they want will make repeated demands of the service, or the cost will simply be pushed elsewhere (Bartlett 2009). Thus, public sector savings are not only achieved by delivering services in an economic or efficient manner, but also by making them work effectively.

\section{Rationale for public sector efficiency}

Keeping the broader perspective on performance in mind, several reasons for looking at the government efficiency can be considered. First, a high share of public expenditure in GDP generates distortive taxation. ${ }^{3}$ In that sense, any inefficient use of public means weighs on the economy as a whole. The second reason is also of a budgetary nature, as an ambitious fiscal policy is requested to deal with the costs of an ageing population and other long-term social, economical and environmental challenges. Given the high share of public expenditure in Belgium (and in Flanders), therein lies a potentially large source of savings that needs to be addressed (Eugène 2008). In other words, when more resources are needed to maintain or even improve the level of public services provided - and raising taxes is not an option, nor is increasing the public debt - there is only one other alternative and that is to squeeze money out of existing levels of expenditure by realizing efficiency gains (Gershon 2006).

Further, a well-functioning public sector is also important in the wider context of efforts to improve the competitiveness of the economy. According to some international rankings, a country's competitive position is largely influenced by characteristics linked to public sector performance as well as to the costs involved (Eugène 2008).

Finally, as a result of the emerging New Public Management paradigm, the focus in the public sector is moving away from a strong input-oriented approach (how much money, people or hours can I get?) towards an emphasis on outputs and outcomes (what can I achieve with this input?) (Pollitt and Bouckaert 2011). Given that public sector resources are namely generated by taxes, citizens and government's clients want "more for their money". Public expectations of outcomes and quality of public services continue to rise. The public have got used to services delivered by the private sector for example, which are now 24/7. Besides that, the public tolerance of inefficiency is reducing. Partly because the media is getting ever sharper at latching onto areas of inefficiency by public sector bodies and making the public more aware of them (Gershon 2006). Linking inputs to outputs (i.e. efficiency) is thus high on the agenda today.

\footnotetext{
${ }^{3}$ Governments raise taxes to finance their expenditure. The level of the tax rate influences the behaviour of people. Economists speak about "distortive taxation", because people make other choices according to the tax rate level. Higher taxes lead to weak incentives for citizens to work and for firms to do business, and thus they have a negative effect on economic growth (Dackehag and Hansson 2012).
} 
Table 1 Five ways to achieve efficiency gains

E1: Making the same output with less input

E2: Making more or better output with the same input

E3: Making more or better output with less input

E4: Making somewhat less output with substantially less input

E5: Making substantially more or better output with somewhat more input

\section{Conceptualization of efficiency gains}

An essential starting point in the debate on a more efficient government is to determine precisely what is meant by the concept of 'efficiency gains' (also often called 'efficiency savings'). We define an efficiency gain as a project, activity, process and/or innovation that generates an increase of the ratio between the outputs produced and the resources (inputs) consumed in producing those outputs. In short, efficiency gains are reflected in the reduction of the input/output ratio. More specifically, as shown in Table 1 above, we can identify five different ways in which an organization can achieve an efficiency improvement.

Efficiency gains can be realized at the input-side (E1, E4), at the output-side (E2, E5), or as a combination of both (E3). Hence, a large degree of differentiation among processes for achieving efficiency gains is possible. We want to stress that even with increasing expenses efficiency gains can occur (E5). If can be proved and motivated that the output will rise more than proportionally to the rise in input costs (so that unit costs decline), then also this kind of efficiency gains has to be considered.

We also emphasize that an output improvement can be achieved either in a quantitative manner (more output) or in a qualitative manner (better output). Efficiency gains are therefore not restricted to a story of less costs (due to a decrease in the resources used) or a higher amount of output, but also the quality of services has to be taken into account. In either case, initiatives for realizing efficiency savings should not happen at the expense of the quality of the public service delivery (see below) (NAO 2007).

It is also noteworthy to point out which types of activities cannot be classified as public sector efficiency savings. These include cuts that result in less or poorer services for the public, increased income purely from higher prices in fees and charges to the public, generating new income sources ${ }^{4}$ (e.g. charging for a service that was not previously charged for), additional income arising from changes in dayto-day demand, re-labeling of activities which involve no change in the inputs or outputs, and transfers of costs and subsidies within the public sector if public services as a whole do not benefit (HM Treasury 2007).

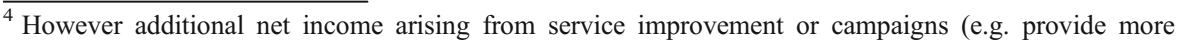
people access to the internet) - after deducting the cost of the campaign — is an eligible efficiency gain.
} 
Cashable and non-cashable efficiency gains

In recent years, mainly drawn from efficiency programs in the British public sector, a distinction is being made between cashable and non-cashable efficiency gains, as illustrated in Fig. 2 below. Cashable efficiencies release financial resources-by reducing inputs (money, people, assets) or reducing prices (procurement, labor costs) - whilst maintaining outputs and output quality, thereby enabling the resources that are released to be diverted to other services (E1), to be recycled within a service to deliver more or better results (E3) or to hold down tax increases. Non-cashable efficiency gains occur when productivity or output quality increases, either for the same resource inputs (E2) or a proportionately smaller increase in resource inputs (E5). In this case, there is no direct financial saving or benefit that is released (HM Treasury 2007; Department for Communities and Local Government 2007). Noncashable efficiency gains are sometimes referred to as 'time-releasing'-efficiencies, mainly to denote that, for instance by rationalization or optimization of certain activities, with the same number of inputs more time can be spent delivering more or better outputs. Attempts to achieve such non-cashable ('time-releasing') efficiency gains are for example a more effective absenteeism policy, a reorganization of the existing workforce or an improved ICT infrastructure.

Typology of efficiency gains

Besides the distinction between cashable and non-cashable efficiency gains, we can also categorize efficiencies by the kind of strategy through which the savings are generated, and based on the organizational domain in which efficiency initiatives are undertaken. Concerning the former, we can generally distinguish five ways of realizing efficiencies. Firstly, efficiency gains can be achieved through simplification or standardization of certain activities, systems or processes. Further, efficiency savings can occur by rationalizing, optimizing or innovating things. Finally, cooperation or partnerships between actors can be set up in order to increase efficiency.

Each of these strategies for efficiency improvement can be applied within different domains of (public sector) organizations. We have selected four main components for the substance (or 'what') of reform projects for realizing efficiency gains. The

Cashable efficiency gains

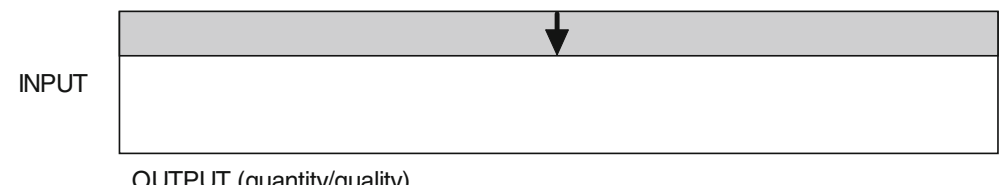

OUTPUT (quantity/quality)

Non-cashable efficiency gains

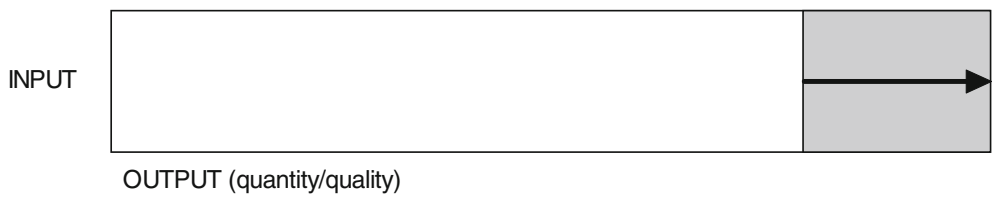

Fig. 2 Cashable and non-cashable efficiencies 
divisions are fairly conventional: financial and budgeting reforms, organizational reforms, changes within the domain of personnel (HRM) and, finally, technological (ICT) modernizations.

Based on the mentioned strategies and the organizational domains in which efficiency projects can be set up, we have developed a typology of efficiency gains as presented in Table 2 below. The five different strategies, within each of the four organizational areas, are illustrated with an example of an efficiency project or reform. We recognize that this typology is not exhaustive, and overlap between several strategies and/or components is of course possible. For instance, rationalization or optimization of a certain process or activity can occur by simplification or cooperation, and technological reforms can be applied at the financial or organizational level. In fact, an increased use of ICT can be found in all the domains of an organization. Above all, innovations will run through all strategies and public sector domains.

\section{Value for money \& quality cross-checks}

According to the above mentioned definition of efficiency gains and summary of what cannot be seen as efficiencies, it may be clear that efficiency does not mean simply implementing cuts in public services or just saving money within public departments by arbitrary budget cuts ('salami slicing'). The efficiency agenda always needs to stand in relationship with effectiveness and quality of service delivery, and in this way being part of a broader 'Value for Money' perspective. 'Value for Money' is high when there is an optimum balance between successful outcomes, high efficiency and productivity, and relatively low costs (Audit Commission 2005).

Consequently, efficiency gains should at least have to maintain the service level, meaning that efficiency projects within public entities might not have a negative

Table 2 Typology of efficiency gains

\begin{tabular}{|c|c|c|c|c|}
\hline $\begin{array}{l}\text { Domain } \\
\text { Strategy }\end{array}$ & $\begin{array}{l}\text { Financial and } \\
\text { budgeting reform }\end{array}$ & $\begin{array}{l}\text { Organizational } \\
\text { reform }\end{array}$ & $\begin{array}{l}\text { Personnel } \\
(\mathrm{HRM}) \text { reform }\end{array}$ & $\begin{array}{l}\text { Technological } \\
\text { (ICT) reform }\end{array}$ \\
\hline $\begin{array}{l}\text { Simplification, } \\
\text { Standardization }\end{array}$ & $\begin{array}{l}\text { e.g. standardizing } \\
\text { subsidy processes }\end{array}$ & $\begin{array}{l}\text { e.g. reforming } \\
\text { intermediate } \\
\text { government } \\
\text { structures }\end{array}$ & $\begin{array}{l}\text { e.g. simplification } \\
\text { of employee plans }\end{array}$ & $\begin{array}{l}\text { e.g. unique electronic } \\
\text { front office }\end{array}$ \\
\hline Rationalization & $\begin{array}{l}\text { e.g. policy-oriented } \\
\text { budgeting process }\end{array}$ & $\begin{array}{l}\text { e.g. rationalize } \\
\text { management } \\
\text { support functions }\end{array}$ & $\begin{array}{l}\text { e.g. rationalize } \\
\text { staffing } \\
\text { requirements }\end{array}$ & $\begin{array}{l}\text { e.g. rationalize } \\
\text { ICT-infrastructure }\end{array}$ \\
\hline Optimization & $\begin{array}{l}\text { e.g. optimizing } \\
\text { financial } \\
\text { workflows }\end{array}$ & $\begin{array}{l}\text { e.g. business } \\
\text { continuity } \\
\text { management }\end{array}$ & $\begin{array}{l}\text { e.g. more flexible } \\
\text { training policy }\end{array}$ & $\begin{array}{l}\text { e.g. network } \\
\text { optimization }\end{array}$ \\
\hline $\begin{array}{l}\text { Cooperation, } \\
\text { partnerships }\end{array}$ & $\begin{array}{l}\text { e.g. shared } \\
\text { procurement } \\
\text { platform }\end{array}$ & $\begin{array}{l}\text { e.g. shared } \\
\text { service centers }\end{array}$ & $\begin{array}{l}\text { e.g. inter-governmental } \\
\text { personnel mobility } \\
\text { plan }\end{array}$ & $\begin{array}{l}\text { e.g. crossing } \\
\text { databases }\end{array}$ \\
\hline Innovation & e.g. e-procurement & $\begin{array}{l}\text { e.g. virtual } \\
\text { organization }\end{array}$ & e.g. Ideas Management & e.g. eGovernment \\
\hline
\end{tabular}


impact on service quality. Efficiency gains alone, however important, are often not the most essential incentive for public organizations and not the main concern for citizens and clients of public services. Instead, they rather call for effectiveness and quality. Thus, a high level of integration between efficiency on the one hand and qualitative services on the other is required.

\section{Conditions for efficiency gains}

As mentioned in the introduction, the Flemish government is now executing a multiannual program which has to lead to permanent efficiency gains. This program consists of a range of key projects and a large number of more specific initiatives within the different horizontal and vertical levels of government aimed at supporting the general efficiency objective (Vlaamse Regering \& College van AmbtenarenGeneraal 2011). Thereby, the pursued efficiency gains have to be real, comparable, measurable and auditable. As the Flemish Government statement 2009-2014 puts it: "Efficiency savings have to be significant and measurable. Efficiency gains also have to be auditable and have to stand a benchmark with comparable European regions" (Vlaamse Regering 2009).

With real efficiency gains it is meant, on the one hand, that an efficiency improvement at one place might not cause a loss of efficiency at another place (for example by re-allocating resources). On the other hand, efficiency gains have to be substantial and significant, meaning that the savings have to compensate the costs that are made for achieving the efficiency gain (for instance, costs of improving a service process).

Because of the striving for a decisive Flemish government that is part of the top five regions in Europe (ViA Pact 2020 2009), efficiency gains in the Flemish public sector also have to be comparable. Therefore, appropriate and comparable indicators have to be selected, because benchmarking for Flanders requires that comparisons are made at the level of regions, and not at the level of countries. The OECD's 'Governance at a Glance' indicators can provide a useful starting point for collecting regional information that can be used for comparison purposes. The conditions of measurability and auditability will be discussed in the next sections.

Furthermore, we suggest adding at least two criteria to this list of conditions for efficiency gains. First of all, it is also important that efficiency savings are sustainable, and thus can be held on a long-term basis. It is therefore recommended that the efficiency-agenda is integrated into the strategic and operational budget plans, and fits within a general perspective of performance management. Secondly, also as a longterm objective, efficiency has to be embedded into the culture of the public sector so that achieving efficiency gains is a routine requirement (Committee of Public Accounts 2006). To sum up, efficiency is not an 'add on', a separate program from the 'core business'. Efficiency is the way 'core business' has to be delivered and improvements in the quality of public services secured (NAO 2006).

Finally, an additional (but not less important) condition for making efficiency programs successful, is to provide a structural linkage between financial and nonfinancial information. After all, relating financial information about the resources used to information about the output produced with these inputs is essential to assess and to evaluate efficiency. Performance budgeting initiatives, that are concerned with 
using performance information in budget processes and resource allocation, are therefore of high importance (OECD 2007). In that respect, to facilitate the evaluation of efficiency in Flanders, it is crucial that this integration of financial and nonfinancial information is stated clearly in the Flemish 'Government Accounts Decree' (Comptabiliteitsdecreet).

\section{The process of measuring and reporting efficiency gains}

In order to assess if efficiency programs (with underlying projects, reform initiatives and/or innovations) actually lead to the forecast efficiency savings, and to report, compare and audit these gains, it is of course necessary for efficiency gains to be measurable. To support this condition of measurability, a stepwise approach can be applied. As shown in Fig. 3 below (HM Treasury 2007; own interpretation), we consider five steps in the measurement and reporting process for efficiency gains. In what follows, we describe these five phases more in detail.

Step 1: Identify and describe the potential efficiency gains

In a first phase, the different projects and initiatives have to be described in terms of (a) the kind of efficiency savings that are targeted (see the five possible ways in Table 1), (b) how these gains can be achieved, and (c) how much this will benefit the public sector (in terms of releasing resources or in terms of improving output quantity or quality). For reasons of monitoring, auditing and result verification, the identification and formulation of the aimed efficiency gains of the different projects will preferably take place by using standardized project files.

The efficiency identification and description necessarily consist of both a narrative (textual) and a quantitative (numerical) part. In the narrative section, the efficiency project is described in detail. Typical questions that have to be addressed include: 'What type of efficiency gains will be delivered?', 'Are these efficiency gains cashable or non-cashable (time-releasing)?', and 'Which actions and activities will be undertaken to achieve the efficiency savings?'. Other crucial information that has to be provided textually is how the gains will be measured and reported, who will take responsibility, which risks are related to the project, etc. The quantitative part allows to specify numerical (i.e. financial) targets and objectives for the entity that is in charge of the project (e.g. department, agency, policy domain), and provides an overview of how much savings are targeted and where these savings will be achieved.

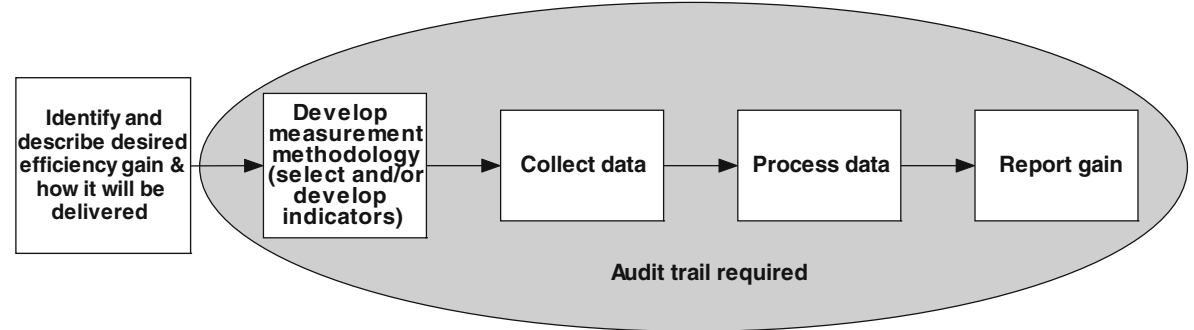

Fig. 3 The process of measuring and reporting efficiency gains 
This quantification of goals is a necessary part of programs for realizing efficiency gains, on the one hand to determine in monetary terms how much savings the program will generate, on the other hand to monitor the program (and the underlying projects) in a better and easier way. All in all, we can call this: 'strength in numbers'.

\section{Step 2: Measurement methodology (select or develop indicators)}

The next stage in the measurement process of efficiency gains (projects) consists of selecting the measurement methodology. In the context of public sector programs, the determination of the measurement method is usually the same as the selection and/or development of appropriate indicators. To measure efficiency within a certain organization, policy domain or government level, and thus to assess the relation between inputs and outputs, it is necessary to develop relevant efficiency indicators (i.e. ratios of inputs and outputs). These efficiency indicators are part of a broader range of socalled performance indicators (PI's), which are used to observe the different relationship between inputs, outputs, outcomes and targets (de Lancer Julnes and Holzer 2008).

Good performance indicators possess several distinctive characteristics such as relevance, simplicity, unambiguousness, reliability, sensitivity, objectivity, controllability, etc. (Hatry 1999; Rochet et al. 2005), and they are comparable and auditable. Indicators are mostly quantitative in nature, although in principle they can also be qualitative (Rotmans and de Vries 1997). Qualitative indicators may be preferable to quantitative indicators where the underlying quantitative information about input and outputs is not available, or the subject of interest is not inherently quantifiable (Gallopin 1996).

Furthermore, not only indicators for measuring the resources used or the amount of outputs produced have to be determined. Also the quality of the service delivery has to be measured. On the one hand because an improvement of the output quality (produced with the same or less inputs) is also a way to achieve efficiency gains, on the other hand because of the necessary quality cross-check. This was strongly emphasized in the efficiency programs that were recently implemented in the UK: efficiency gains could only be classified as final gains by the departments (and validated by the responsible actors) when was ensured that service quality has not been adversely affected by the efficiency initiatives (Committee of Public Accounts 2006; Department for Communities and Local Government 2007; HM Treasury 2007).

\section{Step 3: Collect data}

When decided how the efficiency gains will be measured (i.e. when the relevant indicators are developed or selected), the data collection can start, in the first place to set clear baselines before the efficiency activity begins, and then in a later stage again on each of the measurement moments. This data gathering is obviously a crucial

\footnotetext{
${ }^{5}$ Furthermore, it's always best to set a quantitative goal. A number can motivate people because a number has a defined meaning that cannot be changed or misinterpreted. It is what is it. Also, by defining the goals as much as possible (with numbers), a clearer path to get there can be determined.
} 
phase in the measurement process: without data indicators do not have value (literally and figuratively).

The data collection has to take place for each of the indicators, taking into account a minimum of additional administrative efforts for the organizations concerned. As is also the case for the Flemish efficiency program, it is important to mention clearly in the project and/or indicator files which data have to be collected for the selected indicators and how it can be done. Also the sources of the necessary data and the person(s) in charge of the data gathering can be named. Finally, some notifications about the data quality are useful to mitigate the risks of incorrect and unreliable measurement and reporting.

\section{Step 4: Process data}

After the collection, the data have to be analyzed. This analysis will convert the raw data into usable information for assessing the efficiency. To measure if certain projects, processes, reforms or innovations really lead to an increase in the efficiency (or, in other words, lead to an improvement of what the selected indicators are measuring), robust and clear baselines need to be established for all the inputs, outputs and service quality levels that are specified in the measures (indicators) at the start of each efficiency project (see Fig. 4 below). Setting baselines for efficiency measurement objectives will require analyzing reference data about the resources spent (for instance, financial data about the costs of the current process) and about the current output performance level (data about the number of outputs and data about output quality). After the baselines are set, the efficiency activity can be put in place. In a later stage, identical measurements have to be done again for both the input and output side. Based on the reporting of this information, through the efficiency (input/ output) indicators, it can be assessed if the certain efficiency project has really led to the forecast efficiency gains.

\section{Step 5: Report efficiency gains}

The last phase in the measurement and reporting process of efficiency gains is, of course, to report on the analyzed information (see Fig. 4 below), and thus reporting on whether or not the aimed efficiency gains are realized, on the current value of the achieved efficiency savings, and on the progress of the efficiency projects (the evolution of the measured indicators) against the final objectives. A clear, reliable, consistent and transparent reporting of the savings is necessary (a) to ensure the accountability of the people responsible for the efficiency projects and the overall efficiency program; (b) to facilitate the monitoring of the projects and the program at the different administrative and political levels; and (c) to enhance the auditability of the efficiency gains. This means that frequent reporting (depending on the duration of the program and projects, and on the agreements made with the program board, the political level and the audit institutions) is an essential part of public sector efficiency programs.

Similar to the identification and formulation of the efficiency objectives (see step 1), it is necessary to report on the gains not only quantitatively (numerical), but also in a qualitative (textual) manner. The numerical part, of course, will include data on the value 


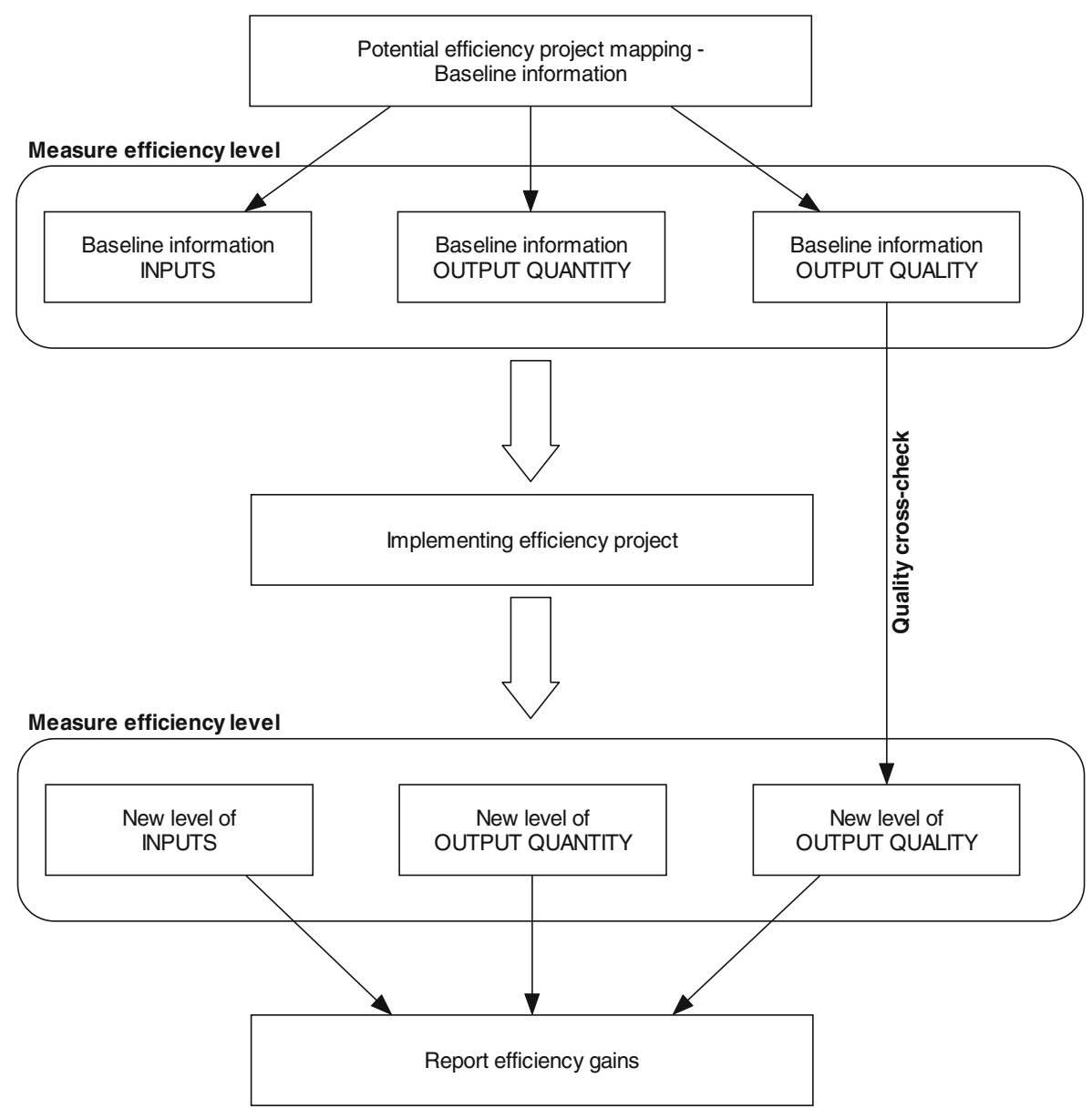

Fig. 4 Information requirements and data processing for efficiency projects

of the efficiency gains achieved thus far since the start of the efficiency project. This quantification has to be based on a cost-benefit analysis, which balances the costs that are made for setting up and implementing the efficiency initiatives against the realized (and quantified) efficiency benefits, so that the real net value of the gains is obtained and reported. Hence, as stated by the Committee of Public Accounts (2006), most of the efficiency projects require up-front investment in order to achieve the benefits in the longer term. To reflect the true increase in efficiency all additional costs, whether oneoff or recurring, should be deducted before gains are reported.

The textual part of the reporting statements allows to describe the 'key actions' and activities that are undertaken to deliver the forecast efficiency savings. The text inserted should be detailed enough for a reviewer to understand what the action(s) being reported are and how they result in an efficiency gain (Department for Communities and Local Government 2007). Besides information on the type and size of the generated savings, the statements should explain how these efficiency gains are measured. This latter means that there has to be reported on the measured inputs and outputs, and on the efficiency indicators developed for the project 
concerned. After all, the evolution of the selected indicator(s) against the set baselines forms the core part of the communication about the progress of the efficiency projects.

Furthermore, the reporting files also have to contain information on the quality of service delivery, in order to demonstrate that the quality has been maintained during the efficiency project and hence that true increases in efficiency are being achieved rather than service cuts (quality cross-check). In some cases, an improvement of the service quality can be the source of achieving efficiency gains (i.e. better output for the same or less inputs). Finally, the report statements have to pay attention to possible dependencies between achieving the efficiency gains and, for instance, legislative initiatives or the implementation and/of finalization of other projects. Also current or possible future risks that can have an impact on the realization of the forecast objectives, and the measures taken to limit or counter these risks, should be mentioned.

\section{Audit of efficiency gains}

It is essential that the above-described process of measuring and reporting efficiency gains is supported with an audit and evaluation trail. Audit of the trajectory towards reaching the efficiency objectives, just as control of the reported (intermediate and final) efficiency gains, is important for the public sector entities involved to have an independent validation of the savings they have achieved. Furthermore, audit helps to ensure that the public and other third parties can have confidence that the efficiency gains as announced by the responsible people are actually realized (NAO 2006).

Concerning the Flemish multi-annual efficiency program 'Decisive Governance', the importance of audit is confirmed by the Flemish Minister of Finance and Budgeting in his policy statement 2009-2014: "The administration has to get the opportunity to come up with efficiency-generating ideas of their own, but these have to be validated by the Internal Audit Service of the Flemish Government. The efficiency gains need to be accounted for in a transparent and consistent manner" (Muyters 2009). Besides the Internal Audit Service of the Flemish Government (' $I A V A$ '), there also might be a role for the National Audit Office ('Rekenhof') as an external auditor of the efficiency program.

Within the framework of efficiency gain programs, audit can take place both at the general level of the program and at the level of the underlying efficiency projects. Thereby, audit should not be limited to an assessment of the efficiency gains and their value. Also the methodologies to measure and report the efficiency savings, and the quality of the data and systems used may be the subject of audit inquiry.

Concerning audit at the level of individual efficiency projects, the validation and review of efficiency gains will mainly be based on the standardized project and reporting statements in order to review the reported (intermediate or final) gains, the measurement methodology used to quantify the gains (the selected indicators), the reliability of the data, and the set baselines. These inspections aim to detect and prevent possible risks which could lead to gains that are not measured properly. For efficiency savings to be reliable, it is crucial that the data used is correct. In addition, audit at the efficiency project level might be useful to assure that the quality of 
services has been maintained (NAO 2007), since real gains only can be obtained when the efficiency initiative does not affect negatively the service quality.

At the global level of the efficiency program, audit aims to function as a general progress control, in order to assess the evolution that is made against the final objectives of the program. This indicates once again the importance of quantifying the efficiency targets. By reviewing the reported values of the different efficiency projects, the auditor can use these numbers to determine the general progress that is made and to make forecast estimates. Finally, audit at the general program level is also useful when it comes to evaluate the consistency of the program, and to assess the governance and coordination mechanisms involved (Stroobants and Bouckaert 2010).

Although the efforts to improve efficiency are of great importance, we conclude by pointing out that audit also has to support government entities in not losing sight of the other important management responsibilities such as insuring service quality, timeliness and effectiveness, increasing client satisfaction, and accomplishing the organizational mission and objectives. In other words, the audit of efficiency gains is ideally incorporated in a broader and coherent system of performance audits, in which the general management responsibilities are stressed and monitored by reporting about the execution of the policy and management contracts, and in which efficiency gains are consolidated at the level of the policy domains to link them with policy effectiveness reports. Stressing efficiency relative to all the other management responsibilities (such as quality and effectiveness) is a complementary, not a competing, goal (Raaum and Morgan 2001). Which brings us back to the beginning of this article.

\section{Conclusion}

With the emergence of the New Public Management (NPM) paradigm in the late 20th century, by which corporate management ideas and theories were brought into government, principles such as economy, efficiency and effectiveness have taken on greater importance in the public sector. Furthermore, the current economic and financial situation, leading to the necessity of carrying out activities with less means, strengthens the attention for efficient governments. This is expressed by the fact that the Flemish Government, following the example of the Netherlands and the UK, is nowadays implementing a multi-year program of achieving substantial efficiency gains in the Flemish public sector. This attention for a more efficient government is of great importance, but should not be allowed to cloud the quality and effectiveness of the service delivery and the government's functioning.

With this multi-year program, titled 'Decisive Government', the major challenge in the coming years for all governments in Flanders, both at central and local level, is to realize significant efficiency improvements. This increase in efficiency or, by definition, a decrease in the ratio of inputs to outputs, can be achieved in different ways, at the side of the resources used as well as at the side of outputs produced, and in terms of input or output quantity as well as in terms of service quality. Hereby, it is important for potential efficiency gains to be significant, measurable, auditable, and comparable with the best performing regions in Europe. By further incorporating the efficiency agenda into the dominant government and administrative culture, and by integrating the efficiency 
objectives into the strategic and operational plans and budgets of government entities, public sector efficiency gains can be realized in a sustainable manner.

To assess if certain initiatives, projects, changes or innovations that are implemented to achieve efficiency gains actually lead to these savings, it is essential that efficiency gains are measured, reported and audited properly. This process of measuring and reporting efficiency gains can be addressed by considering a phased approach in which five stages are distinguished. Firstly, an efficiency project or initiative has to be identified and described, quantitatively (the value of the forecast efficiency gains) as well as qualitatively (which type of efficiency gain is aimed for, and how will this be achieved?). Secondly, a methodology for measuring the efficiency has to be chosen. Within the context of government projects, the determination of the measurement method is usually similar to selecting or developing appropriate indicators. Hereby, not only indicators for the input and output quantity have to be determined, but also the quality of public services has to be measured. Thirdly, when decided how the efficiency gain will be measured, the data collection can start, in the first place to set clear baselines and then in a later stage on each of the measurement moments. Fourthly, after the collection, the data have to be analyzed to turn the raw data into usable information for assessing the efficiency (and comparing the current efficiency with the set baselines or with previous measurement moments). Finally, the last stage of the process involves a clear, transparent, reliable and consistent reporting of the efficiency gains.

This measurement and reporting process has to be supported by an audit trail. Auditing the efficiency gains is important in order to validate, independently, that the reported efficiency saving are actually achieved, and to work out further guidelines to mitigate the risks and to handle the difficulties of public sector entities in measuring and reporting the efficiencies. Audit of efficiency programs is also useful when it comes to evaluate the consistency of the program, and to assess the governance and coordination mechanisms involved.

Acknowledgements The authors wish to thank the editor, the anonymous reviewers, and the participants at the 2nd International Conference on Government Performance Management \& Leadership (Portland, Oregon), in particular Ken Smith and Masami Nishishiba, for their helpful comments and suggestions.

\section{References}

Audit Commission. (2005). Guidance on CPA 2005-Use of resources. London: Audit Commission. Bartlett, J. (2009). Getting more for less: Efficiency in the public sector. London: Demos.

Bouckaert, G., \& Auwers, T. (1998). Prestaties meten in de overheid. Leuven: Instituut voor de Overheid.

Boyle, R., \& MacCarthaigh, M. (2011). Fit for purpose? Challenges for Irish public administration and priorities for public service reform. Dublin: Institute of Public Administration.

Committee of Public Accounts. (2006). Progress in improving government efficiency. Fifty-fifth report of session 2005-06. London: House of Commons.

Dackehag, M., \& Hansson, Å. (2012). Taxation of income and economic growth: An empirical analysis of 25 rich OECD countries, Working Papers 2012:6, Lund: Department of Economics, School of Economics and Management, Lund University.

de Lancer Julnes, P., \& Holzer, M. (2008). Performance measurement: Building theory, improving practice. New York: M.E. Sharpe.

Department for Communities and Local Government. (2007). Measuring and reporting efficiency gains: A guide to completing annual efficiency statements. London: Communities and Local Government. 
Eugène, B. (2008). The efficiency frontier as a method for gauging the performance of public expenditure: A Belgian case study. Brussels: National Bank of Belgium.

Gallopin, G. (1996). Environmental and sustainability indicators and the concept of situational indicators as a cost-effective approach. Environmental Modelling and Assessment, 1(3), 101-117.

Gershon, P. (2004). Releasing resources to the front line. Independent review of public sector efficiency. London: HMSO.

Gershon, P. (13-11-2006). Public sector efficiency-did the Gershon Review make a difference and what comes next? eGov monitor.

Hatry, H. P. (1999). Performance measurement: Getting results. Washington, DC: Urban Institute Press.

HM Treasury. (2007). Measurement of SR04 efficiencies: Guidance on efficiency methodologies. London: HM Treasury.

Leslie, K., \& Canwell, A. (2010). Leadership at all levels: leading public sector organisations in an age of austerity. European Management Journal, 28(4), 297-305.

Mandl, U., Dierx, A., \& Ilzkovitz, F. (2008). The effectiveness and efficiency of public spending. Economic Papers, 301.

Ministerie van Binnenlandse Zaken. (2007). Nota Vernieuwing Rijksdienst. Den Haag: Ministerie van Binnenlandse Zaken.

Muyters, P. (2009). Beleidsnota Financiën en Begroting 2009-2014: Oot-Moedig begroten. Brussel: Vlaamse Overheid.

Muyters, P. (2012). Vlaamse Regering brengt begroting in evenwicht na aanpassing groeiprogrnose, http:// www.philippemuyters.be/vlaamse-regering-brengt-begroting-evenwicht-na-aanpassing-groeiprognose. Accessed 31 July 2012.

NAO. (2006). Progress in improving government efficiency. London: National Audit Office.

NAO. (2007). The efficiency programme: A second review of progress. London: National Audit Office.

OECD. (2007). Improving public sector efficiency: Challenges and opportunities. Paris: OECD.

Peters, B. G., Pierre, J., \& Randmaa-Liiv, T. (2011). Global financial crisis, public administration and governance: do new problems require new solutions? Public Organization Review: A Global Journal, 11(1), 13-27.

Pollitt, C., \& Bouckaert, G. (2011). Public management reform. A comparative analysis-New public management, governance and the neo-Weberian state (3rd ed.). Oxford: Oxford University Press.

Raaum, R., \& Morgan, S. (2001). Performance auditing: A measurement approach. Altamonte Springs: The Institute of Internal Auditors.

Rochet, C., Bout, L., \& Keramidas, O. (2005). The risks of efficiency indicators in the monitoring of public policies. In EGPA 2005-Reforming the public sector. Aix-en-Provence: Institut de Management Public et de Gouvernance Territoriale.

Rotmans, J., \& de Vries, H. (1997). Indicators for sustainable development. Perspectives on global change: The TARGETS approach. Cambridge: Cambridge University Press.

SERV. (2009). Advies over de tussentijdse conclusies van de Commissie Effectieve en Efficiënte Overheid. Brussel: Sociaal-Economische Raad van Vlaanderen.

Stroobants, J., \& Bouckaert, G. (2010). Governance van hervormingsinitiatieven: een internationale vergelijking. Leuven: Steunpunt Bestuurlijke Organisatie Vlaanderen.

Vertinsky, I. (2009). Debate: public management in recessions and economic crises. Strategic options and political constraints. Public Money \& Management, 29(5), 265-267.

ViA Pact 2020. (2009). Pact 2020-doelstellingen: een efficiënt en doeltreffend bestuur (doelstelling 18: Overheid). Vlaamse Overheid: Brussel.

Vlaamse Regering. (2009). Vlaanderen 2009-2014. Een daadkrachtig Vlaanderen in beslissende tijden. Voor een vernieuwde, duurzame en warme samenleving. Brussel: Vlaamse Overheid.

Vlaamse Regering. (2010). De Vlaamse Begroting 2011. Brussel: Departement Financiën en Begroting, Vlaamse Overheid.

Vlaamse Regering \& College van Ambtenaren-Generaal. (2011). Meerjarenprogramma Slagkrachtige Overheid. Brussel: Vlaamse Overheid.

Jesse Stroobants is Researcher at the Public Management Institute of the University of Leuven, Belgium. His research interests include performance management and efficiency issues in the public sector.

Geert Bouckaert is Director and Professor at the Public Management Institute of the University of Leuven, Belgium. He is immediate past-president of the European Group for Public Administration. His research is in the field of performance management, financial management and reform in the public sector. 